\title{
PENEGAKKAN HUKUM SERTA UPAYA PENYELESAIAN SENGKETA ONLINE MARKETPLACE MELALUI MEKANISME ONLINE DISPUTE RESOLUTION
}

\author{
Lusiona Mas Sagala ${ }^{1}$, Devi Siti Hamzah Marpaung ${ }^{2}$
}

${ }^{1}$ Fakultas Hukum Universitas Singaperbangsa Karawang, lusionamassagala@gmail.com

${ }^{2}$ Fakultas Hukum Universitas Singaperbangsa Karawang

\begin{abstract}
The purpose of this study is to determine the regulation of online buying and selling transactions in the Marketplace and consumer disputes that occur in the Marketplace as well as efforts to resolve consumer disputes through the Online Dispute Resolution Mechanism. This study uses a normative juridical method with two types of legal materials, namely primary legal materials and secondary legal materials. Content analysis is used as a form of technique in analysis so that it does not require data in the field. Through this research, it can be seen that the regulation of online buying and selling transactions in the Marketplace is similar to direct or conventional transactions. Even though there is already a policy regarding online transactions, it cannot completely avoid consumer disputes. Therefore, online settlement efforts are needed, namely through Online Dispute Resolution (ODR) with the negotiation, mediation, and arbitration methods.
\end{abstract}

\section{ARTICLE INFO}

\section{Keywords:}

Marketplace; Online;

Dispute; Online Dispute

Resolution

\section{Cite this paper:}

Lusiona Mas Sagala, D. S.

(2021). Penegakkan

Hukum serta Upaya

Penyelesaian Sengketa

Online Marketplace melalui

Mekanisme Online Dispute

Resolution. Widya Yuridika:

Jurnal Hukum, 4(2).

Scope Article

Economic and Business Law

\section{PENDAHULUAN}

Perkembangan yang pesat di dunia sampai hari ini adalah teknologi dan informasi khususnya internet. Dengan adanya jaringan internet maka setiap orang dapat terhubung melalui jarak jauh, mempermudah komunikasi, mendapatkan informasi, dan mendapatkan hiburan. Internet dapat digunakan oleh setiap orang dari usia muda hingga tua dan seluruh kalangan, melalui internet juga setiap orang merasakan kemudahan karena dengan jaringan dan konektivitas yang luas dapat mengurangi biaya untuk transaksi, memudahkan komunikasi, lebih fleksibel, mudah digunakan, interaktif, serta kemudahan untuk membagikan pengetahuan dengan cepat (Laudon, C dan Laudon, 2007). Meningkatnya penggunaan internet menjadi pengaruh untuk peluang usaha bisnis secara online, sehingga kegiatan transaksi jual beli online sangat mempermudah masyarakat dalam pemenuhan kebutuhan sehari-hari. Kegiatan transaksi jual beli online ini dikenal sebagai e-commerce. Hingga kini keberadaan e-commerce semakin berkembang, pengaruh dari perkembangan ini 
juga dirasakan oleh pelaku usaha di mana pendapatannya semakin meningkat dan konsumen dipermudah dengan adanya toko online.

E-commerce menurut Kotler dan Amstrong yaitu saluran secara online yang dapat dijangkau melalui komputer oleh seorang pelaku usaha yang dipergunakan untuk menjalakan kegiatan bisnis, sedangkan bagi konsumen digunakan untuk mendapatkan informasi perihal suatu produk dengan diberikan informasi dan diperkenankan untuk menentukan pilihannya. Selain itu e-commerce dapat dikenal sebagai wadah untuk kegiatan transaksi jual beli secara online dengan memanfaatkan media elektronik dan jaringan internet. Dapat disimpulkan bahwa e-commerce adalah perpaduan media teknologi dam jaringan internet yang menghubungkan pelaku usaha dengan konsumen dalam lingkup yang luas.

Di dunia terdapat banyak jenis e-commerce yang berkembang, namun di Indonesia hanya beberapa jenis yang berkembang. Marketplace adalah jenis e-commerce yang masih berkembang hingga sekarang. Marketplace yang ada di Indonesia yaitu Tokopedia, Shopee, Bukalapak, Lazada, Blibli, Zalora, JD.ID dan lain-lain. Hingga Februari 2021 Marketplace Tokopedia menjadi urutan pertama dengan jumlah kunjungan tertinggi sebesar 129,1 juta per bulannya (Catriana, 2021). Dengan menggunakan Marketplace, pelaku usaha hanya perlu menampilkan gambar dan informasi mengenai produk yang ditawarkan, kemudian konsumen akan memilih dan membeli dengan melakukan transaksi pembayaran, setelahnya pelaku usaha akan mendapatkan notifikasi dari sistem Marketplace untuk memproses pesanan.

Kemudahan yang diberikan dengan transaksi melalui Marketplace menjadi keunggulan karena dapat memudahkan pelaku usaha sebagai penjual dan konsumen sebagai pembeli saat bertransaksi jual beli secara online. Kegiatan transaksi secara online dapat diakses di mana pun berada dan kapan pun selama 24 jam dengan hanya menggunakan media teknologi dan jaringan internet. Proses yang cukup mudah saat bertransaksi yaitu dengan memilih, memesan, membayar, dan menerima barang memang dirasa memudahkan konsumen. Transaksi dengan Marketplace tidak dilakukan secara langsung antara pelaku usaha dan konsumen, namun dengan pihak ketiga yaitu Marketplace. Pihak ketiga dalam hal ini menjadi perantara dengan memberikan pelayanan rekening bersama, di mana pelaku usaha tidak dapat menerima uang yang dibayarkan konsumen sebelum konsumen menerima barang, membantu pelaku usaha untuk menentukan nomor resi, hingga memberikan fasilitas lain yang berguna untuk menarik perhatian konsumen.

Meskipun memudahkan konsumen, nyatanya transaksi secara online dianggap berisiko karena transaksi yang dilakukan tidak seperti pada transaksi konvensional di mana pelaku usaha dan konsumen bertemu langsung untuk melakukan penawaran dan pembelian. Sehingga konsumen hanya bisa melihat gambar dan mengetahui informasi produk tanpa melihat apakah ada kecacatan pada barang yang dikirim, kesalahan produk yang dikirim, pengemasan dan pengiriman yang lama, serta produk yang informasinya tidak sesuai dengan informasi yang ditawarkan. Hal tersebut menjadi awal terjadinya sengketa konsumen. Sengketa ini juga melanggar hak-hak konsumen serta kewajiban para pelaku usaha sebagaimana tercantum dalam Undang-Undang Nomor 8 Tahun 1999 tentang Perlindungan Konsumen, Selain itu, kegiatan ini telah diundangkan dalam Undang-Undang Informasi dan Transaksi Elektronik dan Undang-Undang Nomor 7 Tahun 2014 tentang Perdagangan, dan peraturan perundang-undangan lainnya yang ditetapkan penegakannya secara hukum.

Meskipun sudah ada ketetapan hukum mengenai transaksi jual beli yang dilakukan secara online, namun masih ada pelanggaran yang terjadi sehingga menimbulkan sengketa konsumen. Nyatanya hal tersebut tidak menurunkan minat konsumen dalam membeli produk secara online melalui Marketplace. Hal ini karena beberapa hal, yaitu efisiensi waktu dalam pencarian produk yang mana penggunaan yang mudah mendukung kemudahan dalam mencari produk dan interaksi saat penggunaan Marketplace di mana keamanan, navigasi, dan load time yang mudah dan efisien (Suhari, 2008). Meskipun terdapat 
kemudahan yang diperoleh konsumen, namun tidak dapat mengabaikan permasalahan yang terjadi pada transaksi jual beli secara online melalui Marketplace. Sehingga perlu diupayakan penyelesaian secara online atas sengketa yang dialami antara konsumen dengan pelaku usaha yaitu dengan Online Dispute Resolution (ODR).

Melalui uraian ini diketahui bahwa meskipun terdapat perundang-undangan yang mengatur kebijakan perihal transaksi jual beli secara online melalui Marketplace, namun hal itu tidak dapat menghindari adanya sengketa konsumen. Berangkat dari hal tersebut maka penulis berminat untuk melakukan kajian dengan rumusan masalah perihal bentuk sengketa online pada Marketplace, selanjutnya akan berujung dengan upaya penyelesaian sengketa online dalam Marketplace melalui mekanisme Online Dispute Resolution.

\section{METODE}

Metode penelitian yang digunakan oleh penulis dalam penelitian ini yaitu yuridis normatif. Penelitian secara yuridis normatif di mana peraturan perundang-undangan merupakan hukum yang dirancang secara tertulis atau hukum yang dikonsep sebagai norma yang menjadi patokan berperilaku yang pantas bagi manusia (Amiruddin dan Asikin, 2012). Dengan penelitian ini, pendekatan yang dilakukan yaitu pendekatan kepustakaan dengan menelaah buku-buku yang berkaitan dengan penelitian, peraturan perundang-undangan seperti Undang-Undang Nomor 30 Tahun 1999 tentang Arbitrase dan Alternatif Penyelesaian Sengketa, Undang-Undang Nomor 8 Tahun 199 tentang Perlindungan Konsumen, Kitab Undang-Undang Hukum Perdata, serta dokumen lain yang berhubungan dan sesuai dengan penelitian ini.

Dalam penelitian hukum didasarkan pada kepustakaan, sehingga dikenal sebagai bahan hukum. Pada penelitian ini mengacu pada 2 (dua) jenis bahan hukum (Suardita, 2017) yaitu pertama, bahan hukum primer yaitu bahan hukum yang mempunyai otoritas dan bersifat autoriatif. Bahan hukum primer mencakup peraturan perundang-undangan dan dokumen yang berisi mengenai kebijakan hukum. Kedua, bahan hukum sekunder yaitu bahan hukum yang berisi mengenai penjelasan berupa jurnal, buku-buku, hasil penelitian, artikel, malah, dan lain-lain yang sesuai dengan penelitian yang dibahas.

Setelah mengumpulkan bahan hukum untuk penelitian ini, selanjutnya akan mendapat kesimpulan. Content analysis adalah bentuk teknik analisis pada penelitian ini yang mana tidak memerlukan data pada lapangan. Analisis bahan pada content analysis disebut sebagai teks. Metode analisis yang konseptual dan integrasi cenderung ditujukan untuk mengidentifikasi, menemukan, menganalisis, dan mengolah bahan hukum untuk mengetahui makna, relevansi, dan signifikasinya (Bungin, 2007).

\section{HASIL DAN PEMBAHASAN}

\section{Regulasi Transaksi Jual Beli Online Pada Marketplace dan Sengketa Konsumen}

Transaksi kegiatan jual beli antara konsumen dan pelaku usaha tidak dipungkiri dapat terjadi kapan pun dan di mana pun. Semakin berkembangnya teknologi dan adanya jaringan internet, maka kegiatan transaksi jual beli mulai berkembang menjadi transaksi jual beli secara online dengan memanfaatkan Marketplace. Umumnya Marketplace lebih dikenal sebagai platform yang dipergunakan sebagai tempat kegiatan transaksi jual beli produk secara online. Hingga kini sudah banyak Marketplace di Indonesia, semakin banyaknya Marketplace maka semakin banyak pilihan platform untuk berbelanja dan semakin banyak pilihan harga yang dapat dipilih.

Kemudahan yang didapatkan melalui belanja secara online yaitu karena lebih mudah dalam penggunaannya dan cepat dengan menggunakan media elektronik seperti handphone, tablet, laptop, hingga komputer (Purba, Rohaini dan Septiana, 2018). Selain kemudahan transaksi jual beli dengan memanfaatkan media elektronik, berikut beberapa hal keunggulan dari transaksi jual beli secara online:

1. Transaksi jual beli secara online dapat dilakukan kapan pun dan di mana pun.

Keunggulan dari transaksi jual beli secara online adalah dengan hanya mengandalkan media elektronik seperti handphone, laptop, komputer, dana media sejenis lainnya 
serta adanya jaringan internet. Jual beli secara online dapat dilakukan di mana pun dan kapan pun selama dapat mengakses jaringan internet.

2. Menghemat waktu untuk berbelanja.

Berbelanja biasanya harus meluangkan waktu untuk dapat mengunjungi pasar, mall, atau toko untuk membeli barang yang diinginkan sehingga konsumen harus menyempatkan untuk pergi ke lokasi. Namun dengan adanya transaksi secara online maka konsumen hanya meluangkan waktu untuk memilih dan membayar dari jarak jauh meskipun toko yang dituju berada di luar kota bahkan di luar negeri.

3. Harga yang lebih murah dibandingkan belanja secara langsung di toko atau pasar.

Belanja secara online umumnya akan mendapatkan harga yang lebih terjangkau, karena toko yang menjual produk secara online dapat menekan pengeluaran seperti menggaji sales promotion, membayar kontrakan, dan adanya biaya pengiriman. Selain itu tidak sedikit pelaku usaha yang mendapatkan barang secara langsung produsen sehingga harga yang dibayarkan lebih murah.

4. Ada beberapa pilihan metode pembayaran.

Saat ini setiap transaksi jual beli secara online memberikan banyak mekanisme untuk metode pembayaran, mulai dari transfer melalui bank, kredit card, pembayaran melalui mini market terdekat seperti Alfamart dan Indomaret, dan pembayaran di tempat atau Cash On Delivery.

5. Banyak pilihan produk.

Produk yang dijual secara online beraneka ragam, mulai dari barang yang menjadi kebutuhan sehari-hari hingga barang yang tidak mudah ditemukan pada toko-toko. Sehingga konsumen dapat memilih dan dapat memudahkan konsumen untuk mendapatkan produk sebelumnya kesulitan untuk didapatkan.

Pembeli hanya cukup memesan kapan pun di mana pun dengan menggunakan jaringan internet dan media elektronik, sehingga dalam prosesnya memudahkan pembeli. Setelah melakukan pemesanan, pembeli hanya perlu menunggu hingga barang sampai ke alamat tujuan dengan perantara kurir. Karena memudahkan konsumen, belanja online memang menjadi pilihan bagi masyarakat dari pada transaksi secara langsung (Purba, Rohaini dan Septiana, 2018). Dengan mendapatkan pengalaman demikian, maka transaksi elektronik untuk belanja online sangat digemari oleh masyarakat (Purba, Rohaini dan Septiana, 2018).

Kebijakan yang diterapkan pada transaksi kegiatan jual beli secara online tidaklah berlainan dengan transaksi jual beli secara langsung. Dalam kebijakan sebagaimana tercantum dalam Undang-Undang Nomor 8 Tahun 1999 tentang Perlindungan Konsumen pada Pasal 4 disebutkan bahwa hak-hak konsumen yaitu (Indonesia, 1999):

a. hak atas kenyamanan, keamanan, dan keselamatan dalam mengonsumsi barang dan/atau jasa;

b. hak untuk memilih barang dan/atau jasa serta mendapatkan barang dan/atau jasa tersebut sesuai dengan nilai tukar dan kondisi serta jaminan yang dijanjikan;

c. hak atas informasi yang benar, jelas, dan jujur mengenai kondisi dan jaminan barang dan/atau jasa;

d. hak untuk didengar pendapat dan keluhannya atas barang dan/atau jasa yang digunakan;

e. hak untuk mendapatkan advokasi, perlindungan, dan upaya penyelesaian sengketa perlindungan konsumen secara patut;

f. hak untuk mendapat pembinaan dan pendidikan konsumen;

g. hak untuk diperlakukan atau dilayani secara benar dan jujur serta tidak diskriminatif; 
h. hak untuk mendapatkan kompensasi, ganti rugi dan/atau penggantian, apabila barang dan/atau jasa yang diterima tidak sesuai dengan perjanjian atau tidak sebagaimana mestinya;

i. hak-hak yang diatur dalam ketentuan peraturan perundang-undangan lainnya.

Selain hak-hak konsumen yang harusnya dipenuhi, pelaku usaha juga memiliki kewajiban guna memberikan pelayanan kepada konsumen sebagaimana tercantum dalam Pasal 7 Undang-Undang Nomor 9 Tahun 1999 yaitu:

a. beritikad baik dalam melakukan kegiatan usahanya;

b. memberikan informasi yang benar, jelas dan jujur mengenai kondisi dan jaminan barang dan/atau jasa serta memberi penjelasan penggunaan, perbaikan dan pemeliharaan;

c. memperlakukan atau melayani konsumen secara benar dan jujur serta tidak diskriminatif;

d. menjamin mutu barang dan/atau jasa yang diproduksi dan/atau diperdagangkan berdasarkan ketentuan standar mutu barang dan/atau jasa yang berlaku;

e. memberi kesempatan kepada konsumen untuk menguji, dan/atau mencoba barang dan/atau jasa tertentu serta memberi jaminan dan/atau garansi atas barang yang dibuat dan/atau yang diperdagangkan;

f. memberi kompensasi, ganti rugi dan/atau penggantian atas kerugian akibat penggunaan, pemakaian dan pemanfaatan barang dan/atau jasa yang diperdagangkan;

g. memberi kompensasi, ganti rugi dan/atau penggantian apabila barang dan/atau jasa yang diterima atau dimanfaatkan tidak sesuai dengan perjanjian.

Sebanding dengan transaksi jual beli secara langsung, dalam transaksi jual beli secara online juga menghasilkan suatu kontrak melalui Marketplace. Karena kesamaan ini maka transaksi jual beli secara online melalui Marketplace tetap harus menyesuaikan syarat sah perjanjian atau kontrak yang tercantum dalam Pasal 1320 KUHPerdata yaitu:

1. Sepakat untuk mengikatkan diri.

Penawaran merupakan awal dari kesepakatan oleh suatu pihak yang kemudian ditanggapi oleh pihak lain mengenai penerimaan terhadap penawaran. Apabila penawaran ditolak atau tidak mendapat tanggapan, maka kesepakatan tidak terjadi.

2. Cakap atau mempunyai untuk membuat perjanjian.

Dalam Pasal 1330 KUHPerdata dijelaskan bahwa anak yang belum dewasa, orang dalam pengampuan, dan perempuan yang telah kawin sebagaimana yang telah ditentukan dalam undang-undang, serta secara umum orang-orang yang oleh undang-undang tidak diperkenankan untuk membuat perjanjian tertentu maka dianggap tidak cakap hukum untuk membuat perjanjian.

3. Suatu hal tertentu.

Suatu tertentu yaitu sebuah hasil yang telah tercapai dan harus dipenuhi dalam suatu perjanjian. Ditentukannya prestasi agar dapat menentukan hak dan kewajiban dari para pihak yang membuat perjanjian.

4. Suatu sebab yang diperbolehkan.

Seseorang dapat membuat perjanjian dikarenakan ada suatu sebab. Suatu sebab diperbolehkan apabila tidak bertentangan dengan kesusilaan dan ketertiban umum sebagaimana diundangkan dalam Pasal 1337 KUHPerdata.

Selain syarat sahnya kontrak seperti yang tertulis dalam Pasal 1320 KUHPerdata, transaksi jual beli secara online juga memiliki bentuk kesepakatan dalam kontrak elektronik. Adanya bentuk-bentuk ini menjadi bukti bahwa kebijakan pada transaksi jual beli secara online adalah sah secara hukum. Berikut bentuk-bentuk sepakat dalam kontak elektronik pada transaksi jual beli secara online (Sanusi, 2005): 
1. Electornic Mail (E-mail)

Membuat suatu penawaran dan menerima penawaran dengan mengirimkan ke alamat e-mail offeror (orang yang mendapatkan penawaran) maka suatu kontrak dapat disepakati.

2. Shrink-wrap Contract

Kata shrink-wrap memiliki pengertian yaitu plastik yang berfungsi untuk mengemas kotak barang, umunya kotak barang yang telah dibuka oleh salah satu pihak dapat dinyatakan bahwa orang tersebut telah menyetujui syarat dan kontrak yang ada pada kontrak tersebut. bahwa orang tersebut telah menyetujui syarat dan kontrak

3. Click-wrap Contract

Kontrak yang ada pada perangkat lunak dapat disetujui dengan mengeklik tombol bertuliskan "Saya Setuju”, "I Accept", "I Agree”, dan lain-lain.

4. Browse-wrap Contract

Bentuk persetujuan kontrak yang disetujui dengan mengunduh atau mengeklik tombol yang ada pada halaman website. Dianggap tekah menyetujui dengan menginstal perangkat lunak dari situs web tanpa harus mengeklik pada halaman situs web.

Meskipun mendapat kemudahan dan telah ditetapkannya kebijakan dengan diundangkannya undang-undang yang berkaitan dengan pembelian dan penjualan online, bentuk kontrak, hingga perlindungan konsumen. Namun dalam transaksi jual beli secara online tidak dapat dipungkiri bisa terjadi masalah (Purba, Rohaini dan Septiana, 2018). Karena transaksi dilakukan dengan media elektronik dan jaringan internet, maka pembeli tidak dapat melihat langsung bagaimana wujud dari barang yang dibeli. Berkaitan dengan masalah yang terjadi, berikut faktor-faktor yang menyebabkan terjadinya sengketa dalam transaksi jual beli secara online:

1. Kualitas barang yang tidak sesuai dengan etiket atau label barang.

Pembelian produk secara online yang hanya melihat gambar dan informasi yang ada memang tidak bisa menaruh ekspektasi yang tinggi, karena kita tidak bisa mengetahui bagaimana saat konsumen memberikan produk yang kita mau. Tidak sesuainya dengan pesanan dapat mengakibatkan sengketa karena pelaku usaha melanggar kewajibannya.

2. Informasi yang diberikan tidak jelas atau tidak sesuai.

Hak konsumen yang harus terpenuhi adalah hak atas informasi yang jelas dan benar. Apabila pelaku usaha tidak memberikan informasi yang sebenarnya maka itu termasuk pelanggaran hak konsumen sebagaimana dicantumkan dalam UndangUndang Perlindungan Konsumen.

3. Barang yang dikirim tidak sesuai pesanan.

Dalam jual beli konsumen diharuskan membayar sesuai dengan pesanannya maka pelaku usaha harus memberikan barang sesuai dengan pesanan. Namun hal ini sering kali dilanggar karena tidak adanya pertemuan langsung antara pelaku usaha dan konsumen.

4. Risiko terjadinya penipuan.

Waspada saat belanja online harus diterapkan, karena para pelaku usaha yang tidak menjalankan tanggung jawab dan tidak ada itikad baik rentan melakukan penipuan terlebih transaksi jual beli hanya dilakukan secara online.

Sengketa konsumen yang terjadi dalam jual beli online merupakan yang dimungkinkan sebagai bentuk-bentuk wanprestasi dalam KUHPerdata dalam transaksi jual beli online yaitu (Iqbal, 2018):

1. Tidak melakukan sesuai dengan ketentuan perjanjian.

Dalam transaksi jual beli pada Marketplace, mekanisme pembayaran terjadi apabila konsumen dan pelaku usaha sepakat atas barang yang akan dibeli. Maka konsumen harus membayar seusia dengan pesanan sebelum dapat diproses. Namun sering kali tidak terpenuhinya prestasi oleh pelaku usaha dengan tidak mengirimkan barang, 
sehingga hal itu melanggar ketentuan perjanjian karena hak konsumen yang dilanggar dan pelaku usaha yang tidak menjalankan kewajibannya.

2. Melaksanakan apa yang dijanjikannya namun tidak sebagaimana yang dijanjikan.

Pada saat membeli barang secara online, maka konsumen tidak mengetahui bagaimana kondisi barang yang ditawarkan oleh pelaku usaha. Konsumen hanya dapat melihat dari gambar, deskripsi, dan review dari pembeli yang sudah membeli terlebih dahulu. Karena hal demikian, maka konsumen tidak dapat mengetahui cacat tersembunyi dan dalam hal ini maka konsumen sangat dirugikan.

3. Terlambat memenuhi perjanjian.

Setiap pembeli barang pada Marketplace, setelah melakukan pembayaran maka akan terlihat informasi yang menjelaskan estimasi kapan barang dikirim oleh pelaku usaha. Karena ada batasan waktu, maka apabila pelaku usaha tidak mengirimkan waktu sebagaimana waktu yang ditentukan maka itu menjadi pelanggaran sehingga konsumen mengalami kerugian atas keterlambatan barang yang dikirim.

4. Melakukan sesuatu yang menurut perjanjian tidak boleh dilakukan.

Dalam kegiatan transaksi jual beli secara online maka diperlukan identitas konsumen seperti nama, alamat, email, dan nomor telepon. Informasi tersebut merupakan informasi yang rahasia, sehingga pelaku usaha saat menerima informasi konsumen tidak diperbolehkan untuk menyalahgunakan hingga mengakibatkan kerugian bagi konsumen.

Dengan mengetahui hak konsumen, kewajiban pelaku usaha, syarat sah perjanjian transaksi jual beli online, dan bentuk-bentuk wanprestasi serta mengenai faktor-faktor terjadinya sengketa dalam transaksi jual beli, maka dapat diketahui sumber-sumber sengketa konsumen yaitu:

a. Pelaku usaha yang tidak melakukan kewajiban sebagaimana yang diundangkan dalam undang-undang.

Tidak mengindahkan ketentuan peraturan perundang-undangan mengenai kewajiban pelaku usaha sebagaimana tercantum dalam Undang-Undang Perlindungan Konsumen, maka pelaku usaha dianggar melakukan sengketa yang sumbernya dari hukum, seperti memberikan informasi yang jelas mengenai produk ataupun tidak memberikan pelayanan yang seharusnya dilakukan kepada konsumen.

b. Pelaku usaha atau konsumen yang tidak mematuhi kebijakan dari perjanjian yang ada.

Dengan ini maka pelaku usaha dan pembeli tidak mematuhi perjanjian yang dibuat atau bisa disebut sebagai sengketa yang sumbernya dari kontrak. Seperti pada pelaku usaha yang tidak mengirimkan barang yang jumlahnya tidak sesuai atau mengirimkan barang yang tidak sesuai pesanan. Sedangkan konsumen yang telat membayar pesanan dan tidak memberikan konfirmasi mengenai barang yang diterima merupakan sumber terjadinya sengketa konsumen.

\section{Upaya Penyelesaian Sengketa Konsumen secara Online dalam Marketplace Melalui Mekanisme Online Dispute Resolution}

Umumnya penyelesaian sengketa konsumen diselesaikan dengan 2 (dua) cara yaitu litigasi (dalam pengadilan) dan non-litigasi (di luar pengadilan) (Azwar, 2019). Dalam sengketa perdagangan, penyelesaian sengketa secara litigasi bukan satu-satunya cara. Dilihat dari efisien dan kemudahan, alternatif penyelesaian sengketa atau penyelesaian sengketa secara non litigasi merupakan jalur penyelesaian sengketa yang sering digunakan karena dalam penyelesaiannya disesuaikan dengan kebutuhan masyarakat. Penyelesaian sengketa ini juga lebih cepat dan biaya yang dikeluarkan lebih murah daripada penyelesaian sengketa melalui pengadilan atau litigasi (Candra, 2014). Pengertian Alternatif Penyelesaian Sengketa secara jelas dipaparkan dalam Pasal 1 butir 10 Undang-Undang Nomor 30 Tahun 1999 tentang Arbitrase dan Alternatif Penyelesaian Sengketa bahwa: Alternatif Penyelesaian Sengketa adalah lembaga penyelesaian sengketa atau beda pendapat melalui 
prosedur yang disepakati para pihak, yakni penyelesaian di luar pengadilan dengan cara konsultasi, negosiasi, mediasi, konsiliasi, atau penilaian ahli (Indonesia, 1999a).

Semakin berkembangnya teknologi, saat ini alternatif penyelesaian sengketa dapat diselesaikan secara online dengan menggunakan media elektronik dan jaringan internet. Penyelesaian sengketa secara online dikenal sebagai Online Dispute Resolution, yaitu suatu mekanisme penyelesaian sengketa non litigasi yang diselesaikan melalui internet (Sugiarto, 2019). Penyelesaian sengketa ini dapat dikatakan sebagai penyelesaian sengketa yang terjadi karena pengaruh internet dan seiring dengan perkembangan teknologi. Karena adaptasi terhadap pengaruh internet, maka saat ini Alternatif Dispute Relation masih menjadi pilihan para pelaku bisnis termasuk pada transaksi jual beli secara online. Hal yang menjadi kekurangan dari penyelesaian secara litigasi atau jalur pengadilan yaitu (Iqbal, 2018):

1. Lambatnya proses penyelesaian sengketa.

Dalam penyelesaian sengketa di pengadilan, prosedur pemeriksaan merupakan prosedur yang begitu menghabiskan waktu karena pemeriksaan yang formalistis dan teknis. Sehingga kondisi ini tidak sesuai dengan asas penyelenggaraan kekuasaan kehakiman sebagaimana diundangkan dalam Pasal 2 ayat (4) Undang-Undang Nomor 48 Tahun 2009 tentang Kekuasaan Kehakiman.

2. Biaya penyelesaian perkara yang mahal.

Penyelesaian sengketa di pengadilan memerlukan biaya yang mahal, terlebih jika proses penyelesaiannya yang lama maka semakin memerlukan banyak biaya. Belum lagi memerlukan pengacara yang tidak sedikit.

3. Tidak tanggapnya pengadilan.

Tidak jarang penyelesai sengketa di pengadilan tidak responsif dalam memberikan pembelaan dan melindungi kepentingan umum. Sehingga pengadilan dianggap sering berlaku tidak adil karena hanya memberikan pelayan kepada masyarakat kalangan atas atau orang kaya.

4. Putusan pengadilan yang tidak menguntungkan pihak bersengketa.

Putusan secara objektif dalam pengadilan tidak memberikan kepuasan, ketenteraman, dan kedamaian kepada para pihak karena dianggap merumitkan masalah sehingga perkara sengketa tidak dapat selesai.

5. Keterbatasan kemampuan hakim.

Keterbatasan kemampuan hakim pada abad globalisasi dan iptek di masa kini mengakibatkan sulitnya untuk menyelesaikan sengketa yang kompleks pada berbagai bidang. Hal ini dikarenakan pengetahuan yang dimiliki tidak umum dan hanya berfokus pada bidang hukum.

Online Dispute Resolution merupakan cara penyelesaian sengketa yang sama halnya seperti Alternative Dispute Resolution, perbedaan dari dua alternatif tersebut hanya pada cara kerjanya yaitu secara online di mana setiap sengketa timbul dari adanya aktivitas perdagangan dengan media elektronik (Sugiarto, 2019). Alternatif penyelesaian sengketa pada umumnya terdapat 3 (tiga) pihak yang terlibat dalam penyelesaian sengketa, yaitu pihak yang bersengketa dan pihak ketiga sebagai pihak yang netral. Pada Online Dispute Resolution terdapat pihak lain sebagai pihak keempat yaitu media teknologi yang dipergunakan oleh negosiator, mediator, dan arbiter. Dengan menggunakan media teknologi dan jaringan internet, maka dalam penyelesaian sengketa secara online umumnya diupayakan oleh para pihak yang berada dalam wilayah batas negara (borderless) maupun lintas geografis tanpa harus bertemu muka (face to face) (Azwar, 2019). Jalur penyelesaian ini juga berlaku untuk penyelesaian sengketa perdagangan mengenai kegiatan transaksi jual beli melalui Marketplace. Dalam penyelesaian sengketa secara online terdapat berbagai bentuk metode yaitu online negotiation, online mediation, online arbitration.

\section{Negosiasi Online}

Negosiasi merupakan penyelesaian sengketa secara damai yang mendasar dan tertua yang dipergunakan oleh masyarakat. Negosiasi biasa dikenal sebagai suatu upaya dengan 
cara berkomunikasi untuk mencapai suatu kesepakatan dalam penyelesaian masalah (Azwar, 2019). Negosiasi diupayakan bukan untuk mencari siapa yang menang dan kalah dalam penyelesaian sengketa, namun untuk mempergunakan kesempatan dengan komunikasi yang efektif dan kemampuan sosial untuk mendapatkan hasil kesepakatan bersama yang positif bagi setiap pihak yang bersengketa. Pengertian negosiasi berbeda-beda bagi pihak yang terlibat karena tergantung pada sudut pandang. Namun secara umum dapat dipahami bahwa tujuan dari negosiasi yaitu untuk mendapatkan dan memenuhi kepentingan para pihak yang telah direncanakan guna mendapatkan sesuai dengan yang diinginkan (Hajati et al., 2018).

Dalam negosiasi terdapat dua pihak yang memiliki sudut pandang yang berbeda, maka dari itu dengan negosiasi diharapkan menghasilkan win-win solution. Dalam hal ini, setiap pihak diharapkan mendapat hasil yang memuaskan agar dapat mencapai keberhasilan dari kesepakatan yang ditetapkan. Negosiasi memiliki kelebihan yaitu (Hajati et al., 2018):

1. Para pihak bersengketa diberikan kesempatan yang luas untuk menentukan pilihannya dalam bernegosiasi.

2. Tidak terikat dalam aturan hukum tertulis.

3. Para pihak diberikan ruang untuk menghasilkan kesepakatan win-win solution.

4. Setiap pihak diberikan kesepakatan untuk memberikan penjelasan mengenai berbagai masalah dalam proses negosiasi.

Selain adanya kelebihan, kelemahan dari negosiasi dalam penyelesaian alternatif sengketa yaitu:

1. Tanpa ada kesepakatan dari antara pihak yang bersengketa maka dalam penyelesaian sengketa tidak dapat berjalan.

2. Sering kali terjadi di mana tidak ada salah satu upaya para pihak yang didengarkan kehendak dan keinginannya masing-masing.

3. Menjadi sulit apabila posisi para pihak tidak imbang dalam penyelesaian sengketa.

4. Rentan terjadi kesepakatan yang tidak menguntungkan.

Di era digital di mana negosiasi juga dipergunakan guna penyelesaian sengketa secara online, hal ini biasa digunakan pada sengketa konsumen dengan pelaku usaha pada Marketplace. Negosiasi online merupakan cara yang sederhana dari negosiasi yang biasa dilakukan karena dalam kegiatannya menggunakan media elektronik dan jaringan internet. Tidak ada syarat wajib selain koneksi internet dan itikad baik para pihak yang bersengketa (Widaningsih, 2017). Selain itu, tidak ada keharusan untuk melakukan tatap muka dan menentukan tempat untuk melakukan pertemuan (Widaningsih, 2017). Dengan kemudahan yang didapatkan dan proses yang sederhana maka dapat menghemat biaya.

Pada dasarnya negosiasi online terbagi menjadi dua bentuk. Bentuk pertama adalah Assisted negotiation, negosiasi ini terjadi karena melalui pemberian saran teknologi informasi kepada pihak yang bersengketa. Negosiasi ini dirancang dengan adanya peningkatan kemampuan teknologi guna menghasilkan penyelesaian. Sebelumnya email adalah software yang dipergunakan namun seiring perkembangan dan peningkatan teknologi, terjadi perubahan dengan menggunakan web yang lebih mudah. Dengan menggunakan web, keberhasilan yang didapatkan lebih besar karena web lebih canggih seiring dengan peningkatan dan perkembangan dalam penyelesaian sengketa online (Widaningsih, 2017).

Bentuk kedua yaitu automated negotiation, negosiasi ini dilakukan dengan perbandingan tawaran dengan kesepakatan dengan bantuan komputer dalam mencapai kesepakatan. Karena metode ini tanpa campur tangan manusia, maka metode ini dikenal sebagai penawaran buta di mana semua penawaran yang ada bersifat rahasia, artinya tidak diperlihatkan bagaimana penawaran yang diberikan kepada pihak lawan sampai mendekati kesepakatan. Automated negotiation merupakan bentuk dari assisted negotiation, yang 
membedakan hanya pihak yang dipergunakan untuk menghasilkan penawaran bukan manusia melainkan komputer (Widaningsih, 2017).

Penerapan negosiasi pada Marketplace diupayakan dengan diskusi antara konsumen dan pelaku usaha. Biasanya konsumen akan melakukan kontak dengan menggunakan fitur pesan yang ada pada platform, kemudian menjelaskan masalah yang terjadi saat barang yang di pesan ternyata salah atau tidak sesuai dengan pesanan dan informasi yang diberikan. Sengketa konsumen terjadi memang karena pelaku usaha yang tidak menjalankan kewajibannya sebagaimana diundangkan pada Pasal 7 Undang-Undang Nomor 9 Tahun 1999. Apabila pada negosiasi terjadi win-win solution maka sengketa konsumen dianggap selesai. Namun, apabila tidak selesai maka akan dilanjutkan dengan mediasi yang dilakukan secara online.

\section{Mediasi Online}

Mediasi adalah penyelesaian sengketa di mana dalam penyelesaiannya terdapat pihak ketiga yaitu mediator sebagai pihak yang netral dan dapat bekerja sama untuk mencapai kesepakatan dengan pihak yang bersengketa. Dalam mekanismenya, penyelesaian sengketa menggunakan teknologi sebagai pihak keempat guna mencapai win-win solution. Mediasi memiliki kelebihan dalam penyelesaian sengketa yaitu (Hajati et al., 2018):

1. Biaya yang digunakan murah.

2. Waktu penyelesaian sengketa yang cepat.

3. Keputusan yang dicapai memuaskan bagi pihak yang bersengketa.

4. Kesepakatan yang dapat diterima dengan baik.

5. Keputusan yang dapat dilaksanakan oleh pihak bersengketa.

6. Pemberlakuan keputusan tanpa adanya batasan waktu.

Kekuatan eksekusi merupakan kelemahan mediasi setelah tercapai kesepakatan, karena kesepakatan tercapai karena para pihak yang sukarela. Maka dari itu, mekanisme dalam mediasi dapat efektif diupayakan apabila para pihak yang bersengketa sukarela untuk menyelesaikan perselisihan dengan cara mediasi. Umumnya, mediasi secara online tidak berbeda dengan mediasi yang biasanya, perbedaan hanya dengan menggunakan teknologi sebagai pihak keempat untuk prosesnya penyelesaiannya. Mediasi online terbagi menjadi tiga bentuk yaitu (Abdurrasyid, 2011):

1. Mediasi fasilitatif

Pada mediasi ini fungsi mediator sebagai fasilitator dan tidak diperkenankan untuk berpendapat guna penyelesaian sengketa. Sehingga dalam prosesnya, mediator menyerahkan solusi kepada para pihak yang bersengketa atas sengketa yang dihadapi.

2. Mediasi evaluatif

Dalam mediasi ini mediator berfungsi untuk memberikan pandangan kepada pihak yang bersengketa secara hukum, fakta dan bukti. Mediasi ini mengupayakan strategi dengan membuat suatu kesepakatan atau konsensus yang dapat diterima kedua belah pihak bersengketa melalui mediator dengan mengupayakan solusi dan berusaha untuk meyakinkan para pihak yang bersengketa.

3. Mediasi situasional

Mediator mengupayakan untuk ikut serta dalam permasalahan dengan persetujuan para pihak pada mediasi. Apabila para pihak bersengketa gagal dalam melakukan mediasi di antara maka mediator dapat masuk dalam mediasi yang dilakukan, dalam hal ini mediator dapat ikut serta hanya untuk memberikan solusi jika pihak bersengketa memintanya. Mengupayakan dengan memberikan fasilitas komunikasi antara para pihak dengan mediator dan antara para pihak yang bersengketa merupakan tujuan awal dari mekanisme ini. 
Penyelesaian mediasi biasa dipergunakan dalam sengketa konsumen pada Marketplace oleh konsumen dengan pelaku usaha apabila penyelesaian dengan negosiasi tidak menghasilkan suatu kesepakatan yang menguntungkan para pihak. Mediasi online umumnya difasilitasi oleh platform Marketplace dengan menunjukkan bukti-bukti bahwa terjadi kesalahan saat transaksi jual beli. Mediasi online relatif cepat dan tidak perlu mengeluarkan biaya sehingga dalam penyelesaiannya memudahkan konsumen dan pelaku usaha untuk mencapai kesepakatan.

\section{Arbitrase Online}

Arbitrase merupakan mekanisme penyelesaian sengketa di luar pengadilan yang sering digunakan dalam sengketa business to customers (Suherman, 2019). Dalam penyelesaian arbitrase terdapat arbiter sebagai pihak ketiga. Arbitrase merupakan upaya mengajukan sengketa dengan persetujuan para pihak yang bersengketa kepada satu atau lebih arbiter di mana bertujuan untuk memberikan keputusan yang mengikat atas sengketa yang terjadi. Para pihak yang bersengketa diberikan kebebasan untuk memilih hukum yang dipergunakan dalam proses penyelesaian melalui arbitrase dan putusan yang dihasilkan bersifat final and binding. Kelebihan dari mediasi sebagai alternatif penyelesaian sengketa yaitu:

1. Terdapat jaminan kerahasiaan atas sengketa yang dimiliki para pihak.

2. Terhindar dari keterlambatan karena hal administratif dan prosedural.

3. Pihak yang bersengketa diberikan kebebasan untuk memilih hukum apa yang diterapkan guna menyelesaikan masalah serta proses dan tempat berlangsungnya penyelesaian sengketa.

Namun, kelemahan yang dimiliki dari arbitrase yaitu lembaga arbitrase tidak memiliki kekuatan yang bersifat eksekusi dan kepastian hukum atas kesepakatan yang dicapai. Tidak berbeda dengan arbitrase yang umumnya diketahui, arbitrase online juga menggunakan pihak ketiga yang dibantu dengan teknologi dan jaringan internet sebagai pihak keempat. Pelaksanaan arbitrase online perlu adanya kesepakatan para pihak bersengketa agar dapat dilaksanakan. Kesepakatan yang mungkin dilakukan oleh para pihak saat melakukan arbitrase online yaitu yang pertama, pada perjanjian ditambakkan suatu klausul dalam penyelesaian secara online. Kedua, diberitahukan mengenai pemberlakuan syarat berarbitrase dalam Pasal 8 Undang-Undang Nomor 30 Tahun 1999. Ketiga, dalam proses pelaksanaan ditentukan oleh lembaga arbitrase mengenai online atau tidak.

Dalam arbitrase online, terdapat dua bentuk metode penyelesaian sengketa yang dapat digunakan:

1. Arbitrase mengikat

Penyelesaian arbitrase ini putusannya yang bersifat final, sehingga seperti halnya putusan Pengadilan yang mengikat para pihak.

2. Arbitrase tidak mengikat

Penyelesaian pada arbitrase ini dapat dipilih, boleh untuk diikuti maupun tidak seperti halnya fact finding.

\section{PENUTUP}

Di Indonesia kegiatan transaksi yang dilakukan secara online melalui Marketplace hingga kini semakin meningkat. Hal ini dibuktikan dengan semakin banyak Marketplace yang ada di Indonesia seperti Tokopedia, Shopee, Bukalapak, Lazada, Blibli, Zalora, JD.ID dan lain-lain. Perkembangan Marketplace juga dipengaruhi karena kemudahan yang didapatkan saat bertransaksi jual beli secara online dengan hanya menggunakan teknologi dan jaringan internet. Meskipun demikian, transaksi secara online cukup berisiko karena berbeda dengan transaksi konvensional di mana pelaku usaha dan konsumen bertemu langsung untuk melakukan penawaran dan pembelian. Sehingga, segala kesalahan dan kerugian yang dialami oleh konsumen sulit dihindari 
Dalam keabsahannya, transaksi secara online dan transaksi konvensional memiliki perlindungan yang sama sebagaimana diundangkan dalam Undang-Undang Perlindungan Konsumen. Selain itu syarat sah perjanjian atau kontrak sebagaimana tertulis dalam Pasal 1320 KUHPerdata juga berlaku bagi transaksi secara online. Bukti kontrak pada transaksi secara online seperti electronic mail, shrink-wrap contract, click-wrap contract, dan browsewrap contract merupakan bukti yang sah secara hukum.

Meskipun sudah diatur dalam peraturan perundang-undangan dan banyaknya kemudahan yang didapatkan, namun permasalahan masih ada dalam transaksi secara online. Karena transaksi yang dilakukan secara tidak langsung dan konsumen hanya melihat gambar yang ditampilkan pada Marketplace serta informasi yang mengenai produk, maka pembeli tidak dapat mengetahui kualitas produk yang didapatkan. Selain itu informasi yang tidak sesuai, barang yang tidak dikirim oleh pelaku usaha, hingga risiko penipuan adalah permasalahan yang menjadi sengketa konsumen pada transaksi jual beli secara online. Maka dari itu, sengketa yang diselesaikan secara online diharapkan bisa diselesaikan secara online. Adanya Online Dispute Resolution menjadi alternatif penyelesaian sengketa secara online yang mana terdapat 3 (tiga) mekanisme yaitu online negotiation, online mediation, online arbitration. Dengan adanya tiga jenis mekanisme penyelesaian sengketa online, maka dalam sengketa konsumen dapat diupayakan penyelesaian sebelum sampai ke mekanisme litigasi atau melalui pengadilan.

\section{DAFTAR PUSTAKA}

\section{Buku}

Abdurrasyid, H. P. (2011) Arbitrase Dan Alternatif Penyelesaian Sengketa (APS). Jakarta: Fikahati Aneska.

Amiruddin dan Asikin, Z. (2012) Pengantar Metode Penelitian Hukum. Jakarta: Raja Grafindo Persada.

Bungin, B. (2007) Metodologi Penelitian Kualitatif: Aktualisasi Metodologi Ke Arah Ragam Varian Kontemporer. Jakarta: Raja Grafindo Persada.

Laudon, C, K. dan Laudon, J. P. (2007) Sistem Informasi Manajemen. Jakarta: Salemba Empat.

Sanusi, M. A. (2005) Hukum dan Teknologi Informasi. Jakarta: Tim Kemas Buku.

\section{Artikel Jurnal}

Azwar, M. (2019) "Prospek Penerapan Online Dispute Resolution dalam Upaya Penyelesaian Sengketa Bisnis di Indonesia," Media Iuris, 2(2), hal. 179-196.

Candra, A. (2014) "Penyelesaian Sengketa Transaksi Elektronik Melalui Online Dispute Resolution (ODR) Kaitan dengan UU Informasi dan Transaksi Elektronik," Jurnal Ilmu Komputer, 10(2), hal. 80-89.

Iqbal, J. (2018) "Perlindungan Bagi Konsumen Online Marketplace Melalui Mekanisme Online Dispute Resolution (ODR)," Jurist Diction, 1(2), hal. 257-578.

Purba, J., Rohaini dan Septiana, D. (2018) “Penyelesaian Sengketa Online Marketplace Antara Penjual dan Pembeli Melalui Online Dispute Resolution," Pactum Law Journa, 2(1), hal. 537-549. Tersedia pada: http://repository.lppm.unila.ac.id/13073/1/14324703-1-PB.pdf.

Hajati, S. et al. (2018) Buku Ajar Politik Hukum Pertanahan. Surabaya: Airlangga University Press.

Sugiarto, S. (2019) "Online Dispute Resolution (Odr) Sebagai Alternatif Penyelesaian Sengketa Di Era Modernisasi," Jurnal Qawanin, 3(1), hal. 50-65. 
Suhari, Y. (2008) "Keputusan Membeli Secara Online dan Faktor-Faktor yang Mempengaruhinya," Jurnal Teknologi Informasi DINAMIK, 13(2), hal. 140-146.

Suherman, D. R. (2019) "Abitrase Onlinde Dalam Penyelesaian Sengketa Business Sebagai Wujud Perlindungan Hak Konsumen," Aktualita, 2(2), hal. 584-597.

Widaningsih (2017) "Penyelesaian Sengketa E-Commerce Melalui (ODR) Online Dispute Resolution," Jurnal Panorama Hukum, 2(2), hal. 243-252.

\section{Website}

Catriana, E. (2021) 5 E-commerce yang Paling Banyak Dikunjungi di Indonesia, Kompas.com. Tersedia pada: https://money.kompas.com/read/2021/02/24/072440626/5-ecommerce-yang-paling-banyak-dikunjungi-di-indonesia?page=all (Diakses: $11 \mathrm{Mei}$ 2021).

Suardita, I. K. (2017) "Pengenalan Bahan Hukum.” Bali: Fakultas Hukum Universitas Udayana. Tersedia pada: https://simdos.unud.ac.id/uploads/file penelitian $1 \mathrm{dir} / 7847 \mathrm{bff} 4505 \mathrm{f0416fe0c4}$ 46c60f7e8ac.pdf.

\section{Peraturan Perundang-Undangan}

Indonesia (1999a) “Undang-Undang Nomor 30 Tahun 1999 tentang Arbitrase dan Alternatif Penyelesaian Sengketa."

Indonesia (1999b) "Undang-Undang Nomor 8 Tahun 1999 Tentang Perlindungan Konsumen." 
